\title{
The Fisherman of Halicarnassus and Fernand Braudel: Less than a Full Mediterranean Crossing \\ Eyüp Özveren*
}

\begin{abstract}
The purpose of this article is to identify the convergence between, and the further implications of, the independently developed views and thoughts of two men, Fernand Braudel (1902-1985), the renowned historian, and Cevat Şakir Kabaağaçl1 (18901973), who used the penname of "Fisherman of Halicarnassus" in his literary and historical works. Although the Fisherman is better known for his fiction work, he was really the leader of the Turkish Mediterraneanist movement known as the "Blue Movement." Braudel, a product of the academic-scientific environment, and the inspired Fisherman, who at one point undid his formal education and life so as to remake himself, expressed ideas about the Mediterranean world that were original, influential, and complementary. Towards the end of his life, the Fisherman, who had embraced a local way of life, by making use of his international upbringing and schooling, made an original contribution, yet to be fully acknowledged, to Mediterraneanism at a Mediterranean scale, thereby distinguishing himself from the intellectual habits characteristic of his generation. This paper intends to do justice to his legacy by increasing international awareness of his achievement.
\end{abstract}

Keywords: Fernand Braudel, Cevat Şakir Kabaağaçlı, Fisherman of Halicarnassus, Mediterraneanism, Blue Movement

\section{Özet}

Halikarnas Balıkçısı ve Fernand Braudel: Akdeniz'i Geçerken Yolları Kesişmemiş İki Öncü

Bu yazıda ünlü tarihçi Fernand Braudel (1902-1985) ile edebi ve tarihsel yapıtlarında "Halikarnas Balıkçısı" adını kullanan Cevat Şakir Kabaağaçlı'nın (1890-1973) büyük ölçüde birbirinden bağımsız gelişen Akdeniz'le ilgili görüş ve düşüncelerinin benzerliği saptanmakta ve izdüşümleri irdelenmektedir. Halikarnas Balıkçısı her ne kadar daha çok kurgusal yapıtlarıyla tanınsa da aslında Türkiye'de Mavi Hareketi olarak bilinen Akdenizcilik akımının öncülüğünü yapmıştır. Bilimsel akademik ortamın ürünü olarak yapıt veren Braudel ile bir noktadan sonra kendini sil baştan edip yeniden yetiştiren ve içinden geldiği gibi yazan Balıkçı, Akdeniz dünyası ile ilgili birbirini tamamlayan çok özgün ve etkileyici düşünceler ileri sürmüşlerdir. Balıkçı, yaşamının sonuna doğru, kendi kuşağındaki aydınlardan ayrışarak, yerel bir yaşam biçimini benimsemiş olmakla birlikte, eğitiminden ve gençliğinden edindiği bir uluslararası bakış açısından hareketle Akdeniz dünyası düzleminde gelişen Akdenizcilik hareketlerine ve düşüncesine, değeri henüz tam olarak anlaşılamamış özgün bir katkıda bulunmuştur. Bu yazının amacı, Balıkçı'nın uluslararası görünürlüğünü artırarak hakkını teslim etmektir.

Anahtar sözcükler: Fernand Braudel, Cevat Şakir Kabaağaçlı, Halikarnas Balıkçısı, Akdenizcilik, Mavi Hareketi

\footnotetext{
* Middle East Technical University, Department of Economics
} 


\section{Introduction}

Fernand Braudel (1902-1985) is the most worldwide known French historian of the 20th century. Originally of northern France, he developed an early passion for the Mediterranean that exceeded mere academic specialization. He exerted a formative influence on the development of Mediterranean Studies as a field of study and research in its own right. He was a historian distinguished by his interdisciplinary, if not transdisciplinary, approach. His mastery of French language and literary credentials as manifest in his numerous publications earned him his way to the prestigious L'Académie française in 1984. No wonder why Mediterranean Studies as it exists today is also characterized as the crossroads of different disciplines and approaches, and has become inextricably linked to Braudel's name.

Cevat Sakir (1890-1973, penname "Fisherman of Halicarnassus") was born into a notable family that experienced the fin-de-siècle world on the Ottoman side. His father was related to important statesmen and married into a Muslim Cretan family of distinction while he was posted in Crete. Cevat Şakir was born there and spent his early childhood in Athens where his father was subsequently appointed. Upon the family's return to Istanbul, Cevat Şakir was sent to American Robert College and later to the University of Oxford to study history. He indulged in arts and literature and was thus set on a course to become the first of the several artist or writer celebrities to emerge from this distinguished family. From the successive family and political misfortunes that he suffered, he emerged first and foremost as a major prose writer who revolutionized Turkish literature by adding it genuine local colors and language as well as a sense of poetic realism as of the $1930 \mathrm{~s}^{1}$

While the Fisherman of Halicarnassus was best known within Turkey for his literary work that defies easy translation, it is to another aspect of his career as the intellectual leader of Turkish Mediterraneanism that we give exclusive emphasis in this paper. In the following pages, we explore the independent development of his thought by drawing strong parallels, oblique associations, and momentary convergences with the monumental work of Braudel. By so doing, we hope to make a modest contribution to the further recognition and appreciation of the Fisherman at home and abroad.

\section{Select Highlights of Fernand Braudel's Impact on the Field}

The eminent French historian Fernand Braudel (1901-1985) shaped his-and therefore our-vision of the Mediterranean world as early as the interwar period but wrote his magnum opus ${ }^{2}$ during the Second World War by relying on his memory when he was deprived from access to his sources as a prisoner of war in the once-Hanseatic League port of Lübeck in Germany. This implied he had to carry out a mental elaboration in his mind by speculating more than usual in order to compensate for the disadvantage resulting from the inaccessibility of his sources. ${ }^{3}$ The good side of this deprivation was that he could escape from the tyranny of data if not from the prison itself. He could also liberate himself from the conventional toolbox of historians and approach his subject-matter in a more conceptual and analytical manner. Only after the Second World War, he had the opportunity to revise his work thoroughly by recourse to firsthand material. He thereby gave a few but important final touches to his notion of a

1 For further details of his unusual life story, see İsmet Kabaağaçlı Noonan, Halikarnas Balıkçısı'nın Kızından Anılar Akın Akın (Ankara: Bilgi Yayınevi, 2009); Şadan Gökovalı, Ben Halikarnas Balıkçısı: Doğdum, Sevdim, Öldüm (Ankara: TUREB, 2014), as well as his own autobiographical Mavi Sürgün (İstanbul: Remzi Kitabevi, 1973).

2 Fernand Braudel, The Mediterranean and the Mediterranean World in the Age of Philip II (London: Fontana, 1972 [1949/1966]).

3 Merve İrem Yapıcı, “Bir Akdeniz Tarihçisi: 'Fernand Braudel',” Doğu Batı 34 (2005): 184-86. 
Mediterranean world as a "unit of analysis" distinguished by its predominant unity against a persistent backdrop of diversity that survived the test of the longue durée. Braudel had originally intended to write a broader than merely military history of a series of naval wars between the Habsburg Spain and the Ottoman Empire, extending from Preveza (1538) to Lepanto (1571) in order to establish a dominance over the Mediterranean. ${ }^{4}$ As he did so, he felt obliged to give increasingly more information about the Mediterranean background. In the meantime, the Mediterranean was transformed from being a backdrop and a stage to the unfolding of this historical drama to becoming its major protagonist. This metamorphosis indicates a revolution in the twentieth-century conception of history just as it represents for us the official recognition of an underlying Mediterranean identity that is more than the arithmetic, or for that matter, the geographical and cartographical, sum of its parts.

According to Braudel, the Mediterranean, where rival powers and civilizations contested one another for hegemony, had a singular human geography and history. He concentrated his attention on the "long sixteenth century" which was long enough to cover actually two centuries extending from about 1450 to 1650 . This was the period when the importance of the Mediterranean from the viewpoint of world history first increased-to an all times highpoint in the early modern phase,-and then gradually decreased, particularly in relation with the rise of Atlantic Europe. Hence the Mediterranean experienced a rise and relative decline simultaneous with a directional reorientation. Although Braudel focused on this period for elaborating his analytical framework, he was well aware that its historical background extended to the medieval era plagued with religious warfare that provided the inspiration for the Pirenne Thesis best expressed summarily in his Mohammed and Charlemagne. ${ }^{5}$ Whereas Pirenne had identified a break-up of the Mediterranean into two halves, one Muslim and the other Christian, Braudel was more in accord with revisionist formulations that emphasized the continuity of connections even in the worst of times. In short, the coverage of Braudel's account can easily be stretched back in time. Be that as it may, Braudel's focus on this period was because Mediterranean history in general displayed a pattern of political divisions rather than unity. It would be easiest to focus on the Roman period when the boundaries of the empire included more than Mediterranean in order to emphasize a thesis favoring the unity of the Mediterranean. However, in that exceptional case, the unity originating from the sea would have been lost with all its specificity as it would be overshadowed by the political unity of a centralized empire. By opting instead for the "long sixteenth century," Braudel tested his thesis against a less supportive case. If he could demonstrate that the unity of the Mediterranean operated under these relatively unfavorable circumstances, this would prove his case as applicable to the general pattern rather than the exception of which a single instance-the Roman Empire coincident with an encircled mare nostrum - had been observed. ${ }^{6}$

4 The Fisherman wrote historical novels taking place in the same period which he characterized with exaggeration as an era when the Mediterranean had become an Ottoman-Turkish lake. See, Gökovalı, Ben Halikarnas Balıkçısı, 115.

5 See, Henri Pirenne, Mohammed and Charlemagne (New York: Meridian Books, 1957).

6 When cast against this picture, it becomes obvious that recent critics of Braudel's thesis such as Peregrine Horden and Nicholas Purcell, co-authors of The Corrupting Sea (2000), far from undermining it, serve to elaborate it further. Where Braudel identified a fragile unity-manifest most clearly in exchange-thanks to centripetal forces at work offsetting centrifugal counterforces, the critics added further that the unity Braudel emphasized was even more fragile-that is, far from equilibrium - than he conceived. Moreover, it rested on the overall equilibrium of disparate micro-regions the internal equilibrium of which were at high risk and likely to be unstable, hence they sought a lever in their connectivities with one another thereby resulting in, as well as benefitting from, the reciprocities and overall "equilibrium" of the Mediterranean system. 
Without an awareness of the common denominator constitutive of the Mediterranean unity, Braudel insisted, it would be next to impossible to comprehend the true nature of inter-civilizational relations and borders of all kinds, be they political, diplomatic or cultural. To this day, this remains a complicated issue even when the past is involved. I remember how little things can be indicative of persistent contestations over cultural spaces even very long after the naval wars actually cease and the calm of the sea is restored. Halil Inalcik as a leading historian of the Ottoman Empire was much influenced by Braudel's work. ${ }^{7}$ In turn, he helped shape the minds of a following generation of specialists in the field be they Turkish or otherwise. To this effect he had been a mastermind in the formation of the International Association of Ottoman Social and Economic History in 1988 based on accumulated experience since the first such congress first summoned in 1977 in Ankara. The 2005 congress of this association, to which he could not participate because of his ailing health, was held in Venice. As well as being good business partners, Venice and the Ottoman Empire had contested each other for centuries in the Eastern Mediterranean. The Ottoman Empire had taken Cyprus (1571) and Crete (1645-1669) from Venice thereby relinquishing the latter's status as an actual "maritime empire" in the Levant. In light of these historical facts, the convening of this academic congress with wide participation in Venice was a meaningful choice. Nevertheless, there was a subtler under-side to the event. The exquisite poster of the congress announced the thematic focus of the meeting in Italian and Turkish. In Italian, the theme was expressed as "La Sublima Porta et l'egemonia del Mediterraneo tra Stati e Imperi." In Turkish, the theme was written as "Devletlerle Imparatorluklar arasinda Bâb-ı 'Ali'nin Akdeniz'de egemenliği.'

Anyone who is versed in Italian as well as Turkish would notice that the two specifications do not coincide. The Italian version can be rendered in English as "The Sublime Porte and the Mediterranean Hegemony among the States and Empires," whereas the Turkish can be translated as "The Hegemony over the Mediterranean of the Sublime Porte among the States and Empires." The Turkish version takes for granted that a hegemony over the Mediterranean of the Sublime Porte existed while the Italian version places the Sublime Porte as one of the several rivalrous states and empires vis-à-vis the issue of asserting an exclusive hegemony over the Mediterranean. Behind the two versions are hidden the differences of opinion over the nature of the reality that existed in the first place. Unless two viewpoints were reconciled through further academic discussion and negotiation, there could be no agreement over a technically literal English translation. No wonder why the poster contained all other relevant information than the thematic focus itself in English.

Braudel belonged to the Annales School of historians who sought to reconcile history with (human) geography. As an historian, he was also engaged in a constructive dialogue with the social scientists of his time from which he benefitted greatly. Last but not least, he mastered the French language so well as to qualify for selection as a member to the prestigious L'Académie française usually staffed by the crème de la crème writers and poets of the time. Thanks to his masterful use of language, poetic insight, and his scrupulous penchant for detail ${ }^{8}$ as would befit a qualified novelist, he was as much a humanist in the widest sense of the term as he was an eminent and path-breaking historian.

While many scholars ventured along the direction indicated by Braudel, during the tumultuous 1960s, the presupposition of the "Western Civilization" as the one and only superior civilization was targeted. The Egyptian

7 See, Halil İnalcık, "Impact of the Annales School on Ottoman Studies and New Findings," Review 1, no. 3/4 (1978): 69-96.

8 Peregrine Horden and Nicholas Purcell, The Corrupting Sea: A Study of Mediterranean History (Oxford: Blackwell, 2000), 38. 


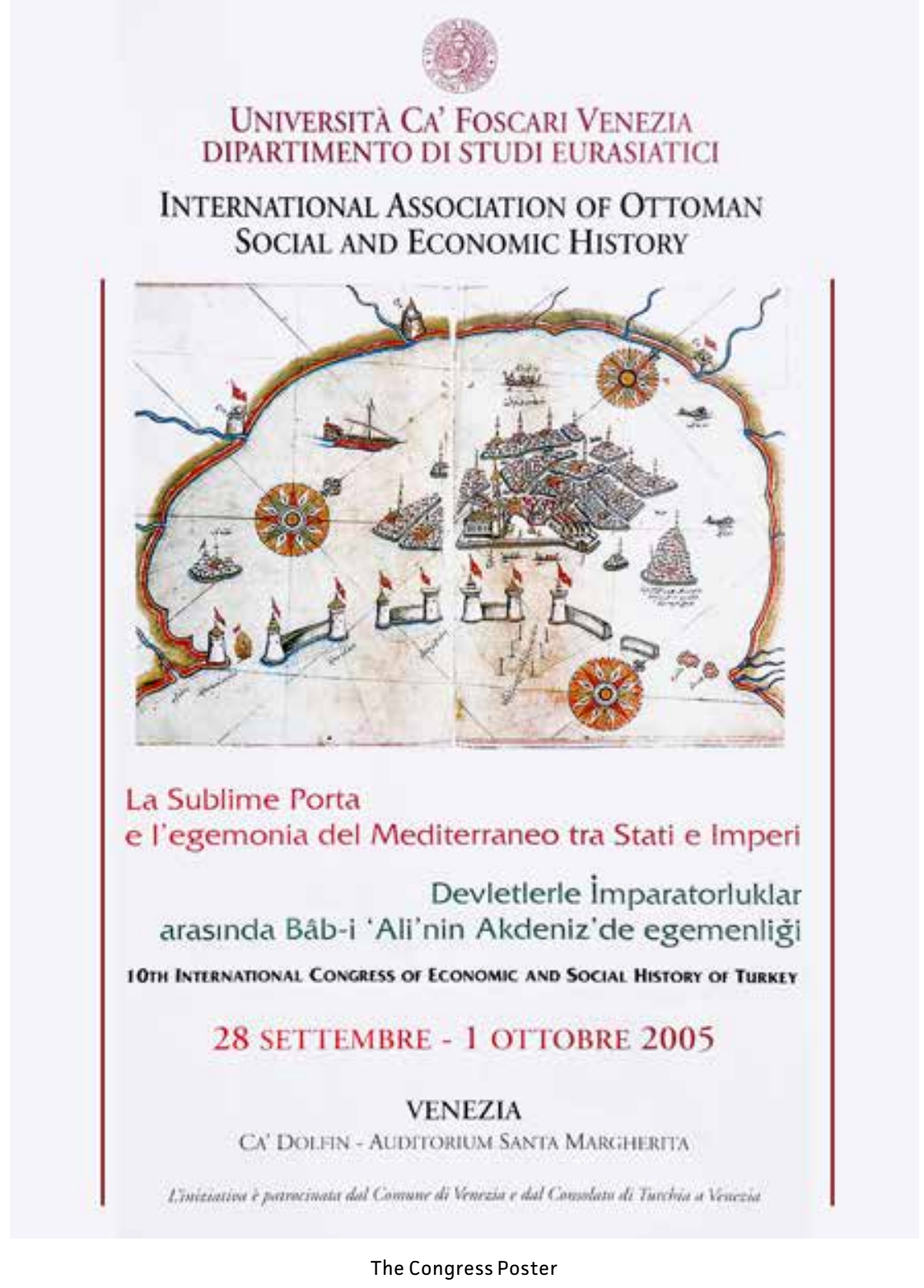

Anuar Abdel-Malek, a precursor of the Palestinian Edward Said and the Egyptian Samir Amin known for their Orientalism ${ }^{9}$ and Eurocentrism ${ }^{10}$ respectively, advanced his thesis of elaborating and activating "civilizational project(s)" that raised Europe's Others to a positional parity and thereby asserted the potential plurality of civilizations. ${ }^{11}$

9 Edward Said, Orientalism (New York: Pantheon Books, 1978).

10 Samir Amin, L'Eurocentrisme: Critique d'une idéologie (Paris: Anthropos-Economica, 1988).

11 Anuar Abdel-Malek, “Orientalism in Crisis," Diogenes 44 (1963): 102-140 and "East Wind: 


\section{The "Local" Fisherman of Halikarnassus Steps into an "International" Debate}

When the above intellectual engagement prompted the re-evaluation of the status of Mediterranean antiquity as a cradle of the so-called Western Civilization, the Fisherman of Halicarnassus, who had until then remained in the sidelines, if not entirely ignorant of such developments, ${ }^{12}$ was ready to make his original contribution. He could do this thanks to his thought that had matured in isolation for over half a century, but also by distilling lessons from his life experience, not to mention the deployment of the limited literature he could lay his hand on under most unfavorable circumstances. A few years before his death, in 1969, the Fisherman addressed a letter to Louis Bayle, the secretary-general of the world think-tank, L'Astrado, of which he was a member. His letter was published with the title "The Sixth Continent: the Mediterranean," and he wrote a sequel to it in 1972 that was posthumously published in 1974 as "The Eternal Youth of the Mediterranean." These two pieces provide us with an excellent point of departure to delineate the Fisherman's conception of the Mediterranean.

The Fisherman's characterization of the Mediterranean as "the Sixth Continent" is quite novel indeed. Before him, many had already noted the importance of the Mediterranean Sea owing to its location at the junction of three continents. The Fisherman did not hesitate to take a major step further:

It is often stated that the shores of three continents, that is, Africa, Asia, and Europe extend along the Mediterranean. This is definitely incorrect. Believing this is believing a simple geographical illusion. Tangier, Algeria, Morocco, Tripoli, and Egypt are not Africa. Africa starts from the Great Sahara. Turkey and Syria are not Asia. Asia starts from the plateau of Iran. All these countries, together with Spain, France, Italy and Greece are neither Asian nor African but first and foremost Mediterranean...13

By characterizing the Mediterranean as a continent in its own right, the Fisherman accomplished a revolution of almost equal significance to that of Braudel ${ }^{14}$ who relocated the Mediterranean from the subordinate status of a backdrop or stage to history to becoming its main protagonist. Braudel proceeded from the "long sixteenth century" as he called it, to characterize the Mediterranean world as one where the rival poles of East and West, as well as North and South, had more or less established a certain balance of power, on the basis of which he had conceived the unity of the Mediterranean. The Fisherman, who in an earlier

The Historical Position of the Civilizational Project," Review 1, no. 1 (1977): 57-64.

12 We do not know how ignorant the Fisherman had remained of these developments. We know that Cevat Şakir stopped over in Marseille on his way back from Oxford. We also know Marseille was the center of some such intellectual debates. Being not an academic, the Fisherman did not have the habit of citing his sources or supporting material in his writings. Hence, he may have known certain reference texts that he did not make explicit. However, from a comprehensive study of Emile Temime, we know that the interwar Marseille was host to debates and publications about the politics of Mediterranean identity. See, Emile Temime, Un rêve méditerranéen: Des Saint-Simoniens aux intellectuels des années trente (1832-1962) (Marseille: Actes Sud, 2002). It should not be farfetched for us to imagine that a few titles of this sort on bookstore display windows in Marseille might have attracted Cevat Şakir's attention. He might also have heard of some such books later from his friends. The origins of the theme of "eternal youth of the Mediterranean" that the Fisherman has written about are also traceable to a French book title of the interwar period. See, Gabriel Audisio, Jeunesse de la Méditerranée (Paris: Gallimard, 1935) and a sequel Sel de la Mer (Paris: Gallimard, 1936) published as the second volume of Jeunesse de la Méditerranée.

13 Halikarnas Balıkçısı, "Akdeniz, Ege ve Arşipel," Demokrat İzmir, July 3, 1955, reprinted in his Arşipel (Ankara: Bilgi Yayınevi, 1995), 73.

14 The Fisherman knew Braudel's work well. He saw his work discussed below as improving upon Braudel's The Mediterranean. See, Gökovalı, Ben Halikarnas Balıkçısı, 125. 
yet formative phase of his life as Cevat Şakir had studied History at Oxford University, in reaction to what he had been taught as the philhellenic foundations of the ultimate superiority of the Western civilization, ${ }^{15}$ counterpoised himself not in the East as against the West, but in the Mediterranean as distinct from Europe and the greater West. He thereby created a rival space from which one could observe things differently. Moreover, he turned to a much earlier phase of history, one when the light came from the East or Orient. ${ }^{16}$ This was an epoch that had witnessed the birth of history and civilization only to be shortly succeeded by the antiquity. ${ }^{17}$ In this way, he could not help hinting the careful reader that the Sixth Continent had actually preceded the others and was truly the First. The Fisherman thus bypassed the merely physical-geographical definition of a continent and rested his case on a cultural definition: "Because, the Sixth Continent is not a savage world. From this point of view, it can be that it is an 'anthropogenic world'.'18 Whereas other continents were divided by mountain ranges and rivers that made transportation difficult and thereby hindered their civilizational unification, the Mediterranean Sea had successfully unified its zone of influence so as to give rise to a common ancient civilization:

As many assume, the sea is not a divisive obstacle. A hundred sea miles in sea would not be as divisive as $10 \mathrm{~km}$. on a mountainous terrain. The sea does not divide but unites. Mediterranean history is a proof of this case. ${ }^{19}$

Nowadays we live in a world where one speaks frequently of unification with reference to the European Union (EU), the North American Free Trade Agreement (NAFTA) zone, and what not. This contemporary phenomenon of worldwide concern with regional unifications should suggest us that these continents had been deeply divided for a very long time. If only we remember this truth, we will realize to what great extent the Mediterranean world as an exception contrasted sharply with the norm that prevailed elsewhere. In juxtaposition, during the 1960s when the bipolar world shaped by the Cold War accustomed people to conceive the state of things in general by reference to divisions, many of the Fisherman's foreign readers were unprepared to work out the logical implications of his Mediterraneanist thought. This is why when his letter aroused interest among the audience, he was invited to contribute a second piece that would open up his way of thinking. In a way befitting to a true fisherman, he described this situation by stating that "the Sixth Continent was a bait, and now the big fish [was] being caught." ${ }^{20}$ In this spirit he authored his subsequent article. This tactical emphasis on his part suggests us that from his viewpoint, the conceptualization of the Mediterranean was of secondary importance no matter how original his

15 Fahri Işık, “Mavi Sürgün'ün ‘Balıkçısı' ve Ege Uygarlığı,” in Ölümünün 25. Yıldönümünde Halikarnas Balıkçısı: Sempozyum Bildirileri (Antalya: T.C. Antalya Valiliği İl Kültür Müdürlüğü Yayınları, 1999), 4.

16 Halikarnas Balıkçısı, “Akdeniz'in Ebedi Gençliği," in his Altıncı Kıta: Akdeniz (Ankara: Bilgi Yayınları, 1974), 29.

17 Braudel also tested some of his inferences from his classic study of the sixteenth-century Mediterranean with the prehistorical and ancient Mediterranean in a book he drafted in 1969. However, the book was posthumously published. See, Fernand Braudel, Memory and the Mediterranean (New York: Knopf, 2001).

18 Halikarnas Balıkçısı, “Balıkçı́nın Mektubu," October 25, 1969, reprinted in his Altıncı Kıta: Akdeniz, 17.

19 Halikarnas Balıkçısı, "Akdeniz, Ege ve Arşipel," 72.

20 The Fisherman quoted by Şâdan Gökovalı, "Akdeniz'in Ebedi Gençliği ve Akdeniz'in Ebedi Genci," in Halikarnas Balıkçısı, Altıncı Kıta: Akdeniz, 10. 
contribution might have been in this respect. For him what counted more was to emphasize the foundational role of Anatolian civilizations within the matrix out of which the human civilization emerged and progressed by way of the Mediterranean world. He was dedicated to this cause. In this respect, for the Fisherman, the Mediterranean emphasis was a means to familiarize outsiders to appreciating the role of Anatolian civilizations. In return, he wished the Turks to wholeheartedly embrace their truly Anatolian identity rather than tracing their legendary ethnic origins to the steppes of Central Asia. This deepening of identity he vied for was a common cause of the Blue Movement he initiated. If he wrote his autobiography as "The Blue Exile," and if Azra Erhat authored a book with the title "Blue Anatolia" (Mavi Anadolu), ${ }^{21}$ this was all evidence for deliberately tainting the natural blue color of the Mediterranean, sometimes more appropriately qualified as turquoise, to Asia Minor. ${ }^{22}$ In spite of the above tactical concern, the Fisherman's contribution to the conceptualization of the Mediterranean world loses nothing of its importance. On the contrary, thanks to his elaborations, we can better understand the nature of a Mediterranean identity as it concerns us today.

First of all, according to the Fisherman, the original smile of life ${ }^{23}$ is being constantly renewed in the Mediterranean. As he put it: "The fertile Mediterranean is always young and lively!" ${ }^{24}$ In this respect, the Mediterranean has preserved the original joy of creation all along and as such, represents a daily situation where culture has not yet alienated humans to nature. This is a persistent primordial condition. Secondly, the Mediterranean has helped nurture by way of promoting seamanship a sort of adventurism in spirit in general. In this context, the Fisherman refers to inspirational role of Odysseus. Among the very children of the Sixth Continent, the imaginary or real, spread to the world, he lists the Ionian seamen listening to the bards recite the Epic of Gilgamesh, ${ }^{25} \mathrm{Homer}^{26}$ with one foot in ancient Mesopotamia and the other in Asia Minor, Odysseus, Euripides, Hippocrates, Plutarch, Dante, Columbus, Magellan, Galileo, Don Quixote and Sancho Panza, and Van Gogh, the Dutch painter riding the tempest, who painted his chair in Provence! ${ }^{27}$ As this last name shows us, Mediterranean-ness is not an attribute that comes with blood but it is acquired by a specific life experience, in fact by remembering our forgotten ancestral roots:

Be that Scandinavian or from Moscow, irrespectively of from where, foreigners are moved by the beauty of the Mediterranean and become enchanted. They feel that what they see before their eyes belongs to their childhood, and they feel that because of some unfortunate and unjust circumstances they have been displaced. ${ }^{28}$

21 Azra Erhat, Mavi Anadolu (Ankara: Bilgi Yayınevi, 1969).

22 See, Gökovalı, Ben Halikarnas Balıkçısı, 138. In a similar vein, Sabahattin Eyuboğlu, in his essay on Iliad and Anatolia related the Turkish War of Independence to the Trojan War in order to emphasize a continuity. On this basis, he emphasized that "New Turkey" was founded not on religious or racial identities but on concepts of "homeland" and "language". See, Sabahattin Eyuboğlu, "İlyada ve Anadolu," in his Mavi ve Kara (İstanbul: Çağdaş Yayınlar1, 1977), 254-61. As the poet Oktay Rifat put it, his generation learned from the Fisherman how to associate themselves with the distant Anatolian civilization and how to consider that civilization as their own past. Moreover, for the Fisherman on this point, see, Gökovall, Ben Halikarnas Balıkçısı, xi and 138.

23 Halikarnas Balıkçısı, "Balıkçı́nın Mektubu," 19.

24 Halikarnas Balıkçısı, "Akdeniz'in Ebedi Gençliği," 62.

25 He took up this theme and further elaborated the connection between The Epic of Gilgamesh and the Iliad and Odyssea of Homer that were about some 1500 years apart. See, Gökovalı, Ben Halikarnas Balıkçısı, 170, and Halikarnas Balıkçısı, Hey Koca Yurt (İstanbul: Hürriyet Yayınları, 1972), 287-90.

26 Halikarnas Balıkçısı, “Akdeniz'in Ebedi Gençliği,” 49.

27 Halikarnas Balıkçısı, "Akdeniz'in Ebedi Gençliği," 54.

28 Halikarnas Balıkçısı, "Akdeniz'in Ebedi Gençliği," 62. 
Last but not least, the Mediterranean has a distinct climate that domesticates humans. In this environment where one can survive with basic clothing throughout the year, climate is "the measure of human being." ${ }^{29}$ The Fisherman argued:

[T]ake the humans from cold climates. Settle them in the Mediterranean. After five years they will become Mediterraneans deep into the marrow in their bones. The sun, the sky, clouds, lightnings, and the sea will be much closer to them then their once native countries. Mankind is as comfortable in the Mediterranean as he is on his mother's lap. ${ }^{30}$

\section{Further Improvisations on a Theme by the Fisherman}

According to the Fisherman, the Mediterranean has a further distinguishing characteristic: "The Mediterranean that possesses a sincere and spontaneous unity meanwhile also continuously produces a prolific variety from within." ${ }^{31}$ This constant state of motion and diversity demonstrates us that the Mediterranean consists of a palimpsest of seaborne geographies. The Fisherman refers to an uncommon and much broader, in fact highly original "Fertile Crescent" 32 one end of which rests in Rome and the other in Carthage. This geography coincides largely with the Eastern Mediterranean of the ancient world. It was once the Mediterranean of its time in one sense, and had played as of then a formative role in the historical construction of the (Greater) Mediterranean world. We should add, as of sixteenth century, the Eastern Mediterranean has receded to the East just as Sicily and South Italy (once an important part of Greater Greece of the antiquity ${ }^{33}$ ) have gradually been redefined as part of the Central and eventually Western Mediterranean. More than any other power, Venice with its maritime empire and deeply entrenched interests in the Levant shouldered the costly weight of this spatial redefinition. No wonder why Venice declined considerably in status; a fact reflected in its increasingly melancholic Baroque that rivalled those of Rome and Naples, its partners in an overall Italian decadence. ${ }^{34}$ Be that as it may, in short, the (Eastern) Mediterranean of the Fisherman as defined with reference to the ancient world, and the Eastern Mediterranean as we understand it in the light of early modern and modern history, do not fully overlap.

In retrospect, by taking off from the works of Fisherman, we can elaborate the conception of Mediterranean further. The Mediterranean of the ancient world was shaped by the collision of several different originally city-state based projects. The origins of the first Mediterranean project are traceable to the Phoenicians. By starting from the Levant, they traversed the Mediterranean westward leaving behind a series of colonies they set up along the routes they had taken. These colonies were intended as much as perpetual ports of call for future periodic crisscrossing. Albeit sparsely woven, the tapestry they constituted became the first Mediterranean of historical times actually realized. A strategic stepping stone between the Levant and the western half of the sea

29 Halikarnas Balıkçısı, "Balıkçı'nın Mektubu", 25.

30 Halikarnas Balıkçısı, "Balıkçı́nın Mektubu", 25.

31 Halikarnas Balıkçısı, "Akdeniz'in Ebedi Gençliği," 29.

32 The normal connotation of the phrase refers to Northeast Africa and Southwest Asia, but more specifically, Lower Egypt on the Nile is on the one end and the Persian Gulf on the other, therefore delineating in addition the coastal parts of geographical Syria and the riverine Mesopotamia.

33 De la Grèce à Rome: Tarente et les lumières de la Méditerranée, Exhibition catalogue. Saint-Mourdes-Fosses: Éditions Sépia, 2009.

34 See, Fernand Braudel, Le Modèle italien (Paris: Flammarion, 1994). 
was the colony of Carthage that quickly outgrew its initial role and eventually challenged Rome. Nevertheless, the Phoenician construct did not penetrate beyond the coastal areas in general, and remained much less effective in the northern part of the Eastern Mediterranean in particular. ${ }^{35}$ From a different viewpoint, this sub-geography was spared for the Greeks who followed in the footsteps of the Phoenicians for doing more of the same but by concentrating their efforts in a different direction. The latecomer Greeks had to take the Phoenician Mediterranean for granted, and looked elsewhere for their expansion. This second Mediterranean project, spread over Sicily and South Italy, but also in the Black Sea world ${ }^{36}$ that became a target of colonization by Ionian cities led by Miletus, ${ }^{37}$ only to include ultimately ports on the northern half of the Western Mediterranean such as Marseille first set up as Massilia by Phokaia (Foça) in western Asia Minor. In this Greek-based Mediterranean project, Black Sea was conceived as an integral part of the Mediterranean world, whereas the western half of the Mediterranean was conceived as far more marginal, ${ }^{38}$ in fact, a kind of early Wild West. Shortly, the Mediterranean as we understand now had never been fully integrated under Greek domination thus becoming a Greek lake. ${ }^{39}$ The Phoenician and Greek Mediterraneans co-existed side by side and they were more complementary (in making up loosely a Great Mediterranean) than being rigidly separated ${ }^{40}$ and self-contained substitutes in a constant state of rivalrous competition. Nevertheless, centrifugal tendencies were at least as strong as centripetal ones, if not more. What Rome accomplished was to subjugate the Wild West, vanquish its only rival Carthage, and using its power-base in the Western Mediterranean along with its central strategic location, to conquer the Eastern Mediterranean and the Black Sea world. ${ }^{41}$ The Roman project of the Mediterranean evolved into an all-inclusive imperial project. The Roman Empire thus became simultaneously a Mediterranean Empire. ${ }^{22}$ This is an exceptional case in history insofar as a single empire ruled over all the shores of the Mediterranean and, in fact, much more, during its prime time. The mare nostrum project of Rome is therefore the largest Mediterranean project actually come true in history. It is one and only in this respect. With its uniform monumental ruins surviving all along the Mediterranean that attest to its unity, it strikes the visitor even today as an exceptional and magnificent accomplishment. Even so, for those of us who are more excited by the diversity attribute and horizontal connectivities and dialogue thereof that the Mediterranean cultivates as well as the multiple exchanges among peoples it facilitates, Rome falls short of offering

35 See M. E. Aubet, "Les Phéniciens dans le Bassin méditerranéen," in La Mediterranée des Phéniciens de Tyre à Carthage. Exhibition catalogue, Institut du monde arabe (Paris: SOMOGY Éditions d'Art, 2008), 38-47.

36 See, Irad Malkin, "Networks and the Emergence of Greek Identity," in Mediterranean Paradigms and Classical Antiquity, ed. Irad Malkin (London: Routledge, 2005), 56-74.

37 The Fisherman noted that the Anatolian city of Miletos set up along the Mediterranean and Black Sea, even on the Atlantic coastline of Spain more than eighty settlements. See, Halikarnas Balıkçısı, Anadolu'nun Sesi (İstanbul: Yeditepe Yayınları, 1971), 104.

38 Bora Ercan, Odysseus Adalart: Bir Akdeniz Yolculuğu (İstanbul: Paloma, 2008), 98.

39 Braudel, Memory and the Mediterranean, 225.

40 Alain Bresson, "Ecology and Beyond: The Mediterranean Paradigm", in Rethinking the Mediterranean, ed. W. V. Harris (Oxford: Oxford University Press, 2005), 101-2.

41 That the Roman victory over Hannibal, if not over Carthage, was far from complete is best attested by the remnants of Hannibal's campaign that have passed the test of time and survive in ruins as well as numerous names as depicted in a spectacular contemporary travel account tracing the footsteps of the ingenious general. See, Paolo Rumiz, L'ombre d'Hannibal (Paris: Gallimard, 2012).

42 Horden and Purcell, The Corrupting Sea, 23. 
us an inspiring model today as it did to the notorious "Third Rome" of the socialist-gone-berserk Benito Mussolini of the interwar period. ${ }^{43}$

After the fall of the Roman Empire, the fault lines of this artificially imposed unity were quickly reactivated. Hence the Mediterranean came to disclose its characteristic vibrant diversity once again. One major contribution the Fisherman made to the conception of the Mediterranean is precisely in this respect. ${ }^{44}$ As we saw above, the Fisherman was an intellectual who articulated his impressions and thoughts in the light of his daily living experience in the first place. After having spent so many years in Bodrum, he could easily differentiate the Mediterranean and the Aegean in his sight as well as in his mind, at a time when the distinction was far from clear to many a scientist and academic. In a letter dated June 10, 1958 to his companion, Azra Erhat, he speaks of his intention to write a book in English entitled as "Aegean World."45 Hence he was already well aware that the Aegean constituted almost a separate world within the Mediterranean. In another letter, he addressed to Erhat, dated November 1, 1958, he expressed his desire to know what she thought about "this Mediterranean-Aegean issue". ${ }^{46}$ In this book, the Fisherman conceives a separate part with its own title, "The History of the Aegean Sea during the Classical Period." ${ }^{\prime 7}$ By so doing, he defines the Aegean as a historical "unit of analysis" just as Braudel had done with the Mediterranean. In this way, he replicates Braudel's achievement but with respect to the Aegean sub-unit. This is yet another "first" by the Fisherman. He informs us that the ancient Egyptians characterized the Aegeans as "the people inhabiting the heart of the sea," and the name of the sea might have originated in a very old local language from a latent meaning such as "the Ancient Sea" or the "the Sea of the Ancients." is no meager achievement to realize that the Aegean, by virtue of its relatively autonomous and self-contained transportation-friendly geography, had indeed been a privileged sea in its own right, constitutive of the Mediterranean then yet to be made. He went further. The Levant-centered Eastern Mediterranean could play such an important role in the making of the Mediterranean world because the Aegean was a sea of almost infinitely many islands:

It is there [in the Aegean] that the Mediterranean belongs most to the Mediterranean; it becomes the Mediterranean to the utmost degree. There the sea and the shore interpenetrate so much so that becomes almost impossible to distinguish where the land ends and where the sea starts. It is a madness of gulfs, small bays, promontories, peninsulas and islands. ${ }^{49}$

Truly, neither in the Black Sea nor in the Western Mediterranean there exists a comparable sea of archipelagos. If there is no second Mediterranean in the

43 See, Franco Cassano, Southern Thought and Other Essays on the Mediterranean (New York: Fordham University Press, 2012), 12-31 and Iain Chambers, Mediterranean Crossings: The Politics of an Interrupted Modernity (Durham, NC: Duke University Press, 2008), 145. For a Mediterranean that could inform an all-embracing and tolerant European project rather than remain subservient to it, see, Predrag Matvejevitch, La Méditerranée et l'Europe (Paris: Fayard, 2005).

44 Unfortunately, this contribution has not been fully recognized and there exists a state of confusion concerning what the Fisherman actually meant. See, Levent Zoroğlu, "Akdeniz ve Halikarnas Balıkçısı," in Ölümünün 25. Yıldönümünde Halikarnas Balıkçısı: Sempozyum Bildirileri (Antalya: T.C. Antalya Valiliği İl Kültür Müdürlüğü Yayınları, 1999), 6.

45 Azra Erhat, Mektuplarıyla Halikarnas Balıkçısı (İstanbul: Çağdaş Yayınları, 1976), 131.

46 Erhat, Mektuplarıyla Halikarnas Balıkçısı, 157.

47 Halikarnas Balıkçısı, Anadolu'nun Sesi, 113-119.

48 Gökovalı, Ben Halikarnas Balıkçısı, 86. For an alternative explanation of the name of the sea that emphasizes the nature of its frequent waves in relation with the Greek word "aiges," see, Ercan, Odysseus Adalari, 42-43.

49 Halikarnas Balıkçısı, "Balıkçı́nın Mektubu", 17-18. 
world, ${ }^{50}$ there is also no second Aegean within the Mediterranean, and hardly anything coming close to it in the world. ${ }^{51}$ If humans in our geography have gradually been transformed into Mediterraneans, this has been largely due to their attraction by the lure of the sea working its effects through these chains of islands..$^{52}$ The Fisherman depicted poetically the advent of the humans from the mainland to the islands:

A few Mediterraneans stopped their rigged horse-carriages. They whipped their animals away and left their carriages behind in order to ride their boats. They harnessed the blue winds from the sky to their boats and tied them fast... When there was no wind, they rowed. Because of either fog or anything else, if at night, they could not see the shore some fifteen miles away, they turned their boats to the smell of oregano, thyme, gorse, and orange blossom coming from the land and reached their homes. ${ }^{53}$

In this favorable environment, the Carians marveled in boat-building while the Phocaeans led others by a wide margin in the fields of anchor and sailcloth making. ${ }^{54}$ Be that as it may, the Fisherman's Aegean sub-identity lying beneath his Mediterranean identity enriched him all the more. It was not only the result of an exile-forced or voluntary-in Bodrum but had deep Cretan roots in a childhood and family tree. Both for the Fisherman, the quintessential Mediterranean, and for the Mediterranean civilization he taught us, in the beginning was Crete. Let us recall that Homer, the poet of the Aegean, described Crete as "island in the middle of the wine-colored sea." ${ }^{55}$ For the Fisherman much inspired by Homer, Crete was the cradle of Mediterranean civilization: "Yes, the Island of Crete, is unquestionably the hearth of the Mediterranean"56 because

50 The epigraph Braudel used for his The Mediterranean dated from a book named The Naturrall and Morall Historie of the East and West Indies by Joseph Acosta, published in English translation in 1604, and attested to the uniqueness of the Mediterranean: "To this day they have not discovered at the Indies any mediterranian sea as in Europe, Asia and Afrikke." [Spelling errors are in the original] (Jacosta quoted in Braudel, The Mediterranean, vol. I, 5. Braudel was of the same opinion. Scholars inspired by Braudel have applied with considerable success his analytical scheme developed for the Mediterranean to domains as disparate as the Atlantic Ocean, Baltic, the Black Sea, the Red Sea, the Indian Ocean and the Sea of China. For some examples, see, Barry Cunliffe, Facing the Ocean: The Atlantic and its Peoples (Oxford: Oxford University Press, 2001); K. N. Chaudhuri, Trade and Civilisation in the Indian Ocean (Cambridge: Cambridge University Press, 1985); Alexis Wick, The Red Sea (Oakland, CA: University of California Press, 2016); Georges I. Bratianu, La Mer Noire des origins à la conquete ottoman (Rome \& Munich: Societas Academica Dacoromana, 1969); Eyüp Özveren, "The Black Sea World as a Unit of Analysis," in Politics of the Black Sea, ed. Tunç Aybak (London: Tauris, 2001), 61-84. The Braudellian metaphor has also been extended to the Sahara! See, David Abulafia, "Mediterraneans," in Rethinking the Mediterranean, ed. W. V. Harris (Oxford: Oxford University Press, 2005), 75. The ultimate verdict on the uniqueness of the Mediterranean remains to be delivered but the more general explanatory relevance of the analytical framework cannot be denied.

51 Bresson, "Ecology and Beyond: The Mediterranean Paradigm", 95.

52 Cem Biçer, our friend and an experienced skipper, once recounted to us how the Muğla-centered Aegean had no counterpart in all Mediterranean because it came with a variety of alternating winds indispensable for sailing. He noted that the Dalmatian coastline, another favorite of yacht captains, was characterized by predominance of a uni-directional wind, which obliged sailors to depend on motor-force for extended time periods when advancing in the opposite direction. Unpleasant as it is now for leisure boat captains, it was a real obstacle on the way of ancient sailors who had no other option but rowing when the sails failed.

53 Halikarnas Balıkçısı, “Akdeniz'in Ebedi Gençliği,” 30.

54 Halikarnas Balıkçısı, Anadolu'nun Sesi, 101.

55 Halikarnas Balıkçısı, "Akdeniz'in Ebedi Gençliği," 39.

56 Halikarnas Balıkçısı, "Balıkçı'nın Mektubu," 22. 
"the famous great sea civilization of the world, the Minoan civilization, was created here." ${ }^{\prime 57}$ The Fisherman, who did not give up making this emphasis in various contexts, also spelled out the connection between Crete and his family tree: "Despite myself being a Cretan [...], I would not want others to think that everything belonged to Crete. But, the greatest share in the Mediterranean reality goes to the Minoan civilization." ${ }^{58}$

\section{Conclusion}

At a time when the knowledge of the Mediterranean was being shaped, the Fisherman of Halicarnassus thus developed his own position and original thought that entailed a universal contribution he based on his life experience. His thoughts were never frozen as is the case with some strictly academic works. They reflected his enthusiasm and heartbeat, if I may say, his "eternal youth." He was well aware of this peculiarity, only he preferred as early as 1954 to trace it not to his character but to that of his subject-matter, be that Anatolia or the Aegean, or the Mediterranean that defied any organized presentation by narration. ${ }^{59}$ His words, phrases, sentences, ultimately long paragraphs rebelled against the taken-for-granted spelling conventions and grammar rules. Frequently he rushed to write, so much so, as to divide up his material into smaller pieces or sub-units; a sign of his compelling anxiety to reach his conclusions. It is as if, once printed, his narrative remains unstable and ready to move on even on paper. This is because he put his lifeblood into what he wrote. He took sides with Dionysus whenever he was faced with the option of rallying with Apol10. ${ }^{60}$ In this respect, having once translated Carmen, and having been a great admirer of the music of George Bizet, he was also as Mediterranean as Friedrich Nietzsche, who parted ways with Richard Wagner's aesthetics and insisted that classical music waited to be Mediterraneanized. ${ }^{61}$ The Dionysian writings of the Fisherman ultimately came to reflect the mirror-image of the Mediterranean Sea itself making waves, constantly in motion but of different rates, occasionally becoming hostage to tempests, only to have their peace restored temporarily, before a thunderstorm broke out. These storms were obviously as much in his hot-blooded temper as they were in the Mediterranean environment.

\section{Bibliography}

Abdel-Malek, Anuar. "East Wind: The Historical Position of the Civilizational Project." Review 1, no. 1 (1977): 57-64.

Abdel-Malek, Anuar. “Orientalism in Crisis.” Diogenes 44 (1963): 102-140.

Abulafia, David. "Mediterraneans." In Rethinking the Mediterranean, edited by W.V. Harris, 64-93. Oxford: Oxford University Press, 2005.

Amin, Samir. L'Eurocentrisme: Critique d'une idéologie. Paris: Anthropos-Economica, 1988.

Aubet, M. E. "Les Phéniciens dans le Bassin méditerranéen." In La Mediterranée des Phéniciens de Tyre à Carthage. Exhibition catalogue, Institut du monde arabe, 38-47. Paris: SOMOGY Éditions d'Art, 2008.

57 Halikarnas Balıkçısı, "Akdeniz'in Ebedi Gençliği," 30.

58 Halikarnas Balıkçısı, "Balıkçı'nın Mektubu," 25.

59 Gökovalı, Ben Halikarnas Balıkçısı, 1.

60 The Fisherman and his friends Sabahattin Eyüboğlu and Azra Erhat, as well as the early Blue Voyagers in their company, elaborated this aesthetic dichotomy further so as to apply it also to Anatolian architecture. In the İsabey Mosque in Selçuk that was completed in 1375 by a Damascene master architect of the name Ali, they identified this aesthetic principle at work because Ali had joyfully and playfully incorporated marbles and stones from the ruins of Ephesus. See, Gökovalı, Ben Halikarnas Balıkçısı, 168.

61 See, Friedrich Nietzsche, The Works of Nietzsche, Vol. XI: The Case of Wagner; The Twilight of the Idols; Nietzsche Contra Wagner; The Antichrist, trans. Thomas Common (New York: The Macmillan Company, 1924). 
Audisio, Gabriel. Jeunesse de la Méditerranée II: Sel de la mer. Paris: Gallimard, 1936.

Audisio, Gabriel. Jeunesse de la Méditerranée. Paris: Gallimard, 1935.

Bratianu, Georges I. La Mer Noire des origins à la conquete ottoman. Rome \& Munich: Societas Academica Dacoromana, 1969.

Braudel, Fernand. Memory and the Mediterranean. New York: Knopf, 2001.

Braudel, Fernand. Le Modèle italien. Paris: Flammarion, 1994.

Braudel, Fernand. The Mediterranean and the Mediterranean World in the Age of Philip II. London: Fontana, 1972.

Bresson, Alain. "Ecology and Beyond: The Mediterranean Paradigm." In Rethinking the Mediterranean, edited by W.V. Harris, 94-114. Oxford: Oxford University Press, 2005.

Cassano, Franco. Southern Thought and Other Essays on the Mediterranean. New York: Fordham University Press, 2012.

Chambers, Iain. Mediterranean Crossings: The Politics of an Interrupted Modernity. Durham, NC: Duke University Press, 2008.

Chaudhuri, K. N. Trade and Civilisation in the Indian Ocean. Cambridge: Cambridge University Press, 1985.

Cunliffe, Barry. Facing the Ocean: The Atlantic and its Peoples. Oxford: Oxford University Press, 2001.

De la Grèce à Rome: Tarente et les lumières de la Méditerranée, Exhibition catalogue. Saint-Mourdes-Fosses: Éditions Sépia, 2009.

Ercan, Bora. Odysseus Adaları: Bir Akdeniz Yolculuğu. İstanbul: Paloma, 2008.

Erhat, Azra. Mektuplarıyla Halikarnas Balıkçısı. İstanbul: Çağdaş Yayınları, 1976.

Erhat, Azra. Mavi Anadolu. Ankara: Bilgi Yayınevi, 1969.

Eyuboğlu, Sabahattin. "İlyada ve Anadolu." In Mavi ve Kara, 254-61. İstanbul: Çağdaş Yayınları, 1977.

Gökovalı, Şadan. Ben Halikarnas Balıkçısı: Doğdum, Sevdim, Öldüm. Ankara: TUREB, 2014.

Halikarnas Balıkçısı. “Akdeniz, Ege ve Arşipel." In Arşipel, 69-74. Ankara: Bilgi Yayınevi, 1995.

Halikarnas Balıkçısı. “Akdeniz'in Ebedi Gençliği.” In Altınıı Kıta: Akdeniz, 29-62. Ankara: Bilgi Yayınevi, 1974.

Halikarnas Balıkçısı. "Balıkçı'nın Mektubu." In Altıncı Kıta: Akdeniz, 17-26. Ankara: Bilgi Yayınevi, 1974.

Halikarnas Balıkçısı. Mavi Sürgün. İstanbul: Remzi Kitabevi, 1973.

Halikarnas Balıkçısı. Hey Koca Yurt. İstanbul: Hürriyet Yayınları, 1972.

Halikarnas Balıkçısı. Anadolu'nun Sesi. İstanbul: Yeditepe Yayınları, 1971.

Horden, Peregrine and Nicholas Purcell. The Corrupting Sea: A Study of Mediterranean History. Oxford: Blackwell, 2000.

İnalcık, Halil. "Impact of the Annales School on Ottoman Studies and New Findings." Review 1, no. 3/4 (1978): 69-96.

Işık, Fahri. "Mavi Sürgün'ün 'Balıkçısı' ve Ege Uygarlığı." In Ölümünün 25. Yıldönümünde Halikarnas Balıkçısı: Sempozyum Bildirileri, 4-5. Antalya: T.C. Antalya Valiliği İl Kültür Müdürlüğü Yayınları, 1999.

Malkin, Irad. "Networks and the Emergence of Greek Identity." In Mediterranean Paradigms and Classical Antiquity, edited by Irad Malkin, 56-74. London: Routledge, 2005.

Matvejevitch, Predrag. La Méditerranée et l'Europe. Paris: Fayard, 2005.

Matvejević, Predrag. Mediterranean: A Cultural Landscape. Berkeley, CA: University of California Press, 1999.

Nietzsche, Friedrich. The Works of Nietzsche, Vol. XI: The Case of Wagner; The Twilight of the Idols; Nietzsche Contra Wagner; The Antichrist. Translated by Thomas Common. New York: The Macmillan Company, 1924.

Noonan, İsmet Kabaağaçlı. Halikarnas Balıkçısı'nın Kızından Anılar Akın Akın. Ankara: Bilgi Yayınevi, 2009.

Özveren, Eyüp. "The Black Sea World as a Unit of Analysis." In Politics of the Black Sea, edited by Tunç Aybak, 61-84. London: Tauris, 2001.

Pirenne, Henri. Mohammed and Charlemagne. New York: Meridian Books, 1957.

Rumiz, Paolo. L'ombre d'Hannibal. Paris: Gallimard, 2012.

Said, Edward. Orientalism. New York: Pantheon Books, 1978.

Temime, Emile. Un rêve méditerranéen: Des Saint-Simoniens aux intellectuels des années trente. 1832-1962. Marseille: Actes Sud, 2002.

Wick, Alexis. The Red Sea. Oakland, CA: University of California Press, 2016.

Yapıc1, Merve İrem. “Bir Akdeniz Tarihçisi: 'Fernand Braudel'.” Doğu Batı 34 (2005): 183-199.

Zoroğlu, Levent. "Akdeniz ve Halikarnas Balıkçısı.” In Ölümünün 25. Yıldönümünde Halikarnas Balıkçısı: Sempozyum Bildirileri, 6-7. Antalya: T.C. Antalya Valiliği İl Kültür Müdürlüğü Yayınları, 1999. 